\title{
Corrosion inhibition of $\mathrm{Mg90}$ alloy by mixtures based on sodium oleate. Influence of oxide film thickness
}

\section{V.A. Luchkina,* (D) Yu.I. Kuznetsov, (iD D.B. Vershok, A.A. Chirkunov, N.A. Salavatov ${ }^{(i)}$ and O.V. Dement'eva}

A.N. Frumkin Institute of Physical Chemistry and Electrochemistry, Russian Academy of Sciences, Leninsky pr. 31, 119071 Moscow, Russian Federation

*E-mail: masildik@mail.ru

\begin{abstract}
The effect of the thickness of the oxide layer formed on commercial magnesium $\mathrm{Mg} 90$ on the efficiency of its anticorrosive protection with sodium oleate (SOl) and formulations based on it was studied. It was shown that in the absence of treatment with the corrosion inhibitor (CI), an increase in the thickness of the oxide-hydroxide film increases the corrosion resistance of $\mathrm{Mg} 90$. The longest protection is provided by a film formed in 10 minutes of degreasing in an alkaline phosphate solution, which is associated with incorporation of the inorganic inhibitor into the coating. Treatment of Mg90 samples coated with different oxide-hydroxide films in aqueous solutions of the CI improves the corrosion resistance. The protection efficiency was estimated in three ways: based on anodic polarization curves recorded in a borate buffer ( $\mathrm{pH}$ 9.2) containing $1.0 \mathrm{mM} \mathrm{NaCl}$; from EIS results obtained in the same solution but at the free corrosion potential, and by accelerated corrosion tests at $100 \%$ relative air humidity with forced daily moisture condensation on the samples. According to the EIS data, the formulation of $12 \mathrm{mM}$ $\mathrm{SOl}+4 \mathrm{mM}$ vinyltrimethoxysilane (VS) was the best mixed CI, in whose solution a one-hour exposure of $\mathrm{Mg} 90$ samples chemically preoxidized in $5 \mathrm{M} \mathrm{NaOH}$ provided a high degree of protection, $Z=99.89 \%$. The mixture of $12 \mathrm{mM}$ IFKhAN $25 \mathrm{~F}+4 \mathrm{mM}$ VS was slightly less efficient $(Z=99.83)$, but it proved to be the best CI in accelerated corrosion tests. FTIR analysis of the Mg90 surface confirmed the presence of CI components on it, and in the case of $12 \mathrm{mM}$ IFKhAN $25 \mathrm{~F}+4 \mathrm{mM}$ VS, a band corresponding to the stretching vibrations of the $\mathrm{Si}-\mathrm{O}-\mathrm{Si}$ bonds was found in the range of $1000-1100 \mathrm{~cm}^{-1}$, indicating the formation of a network of siloxane bonds. This fact, together with the existence a band with a maximum at $3280 \mathrm{~cm}^{-1}$ due to the stretching vibrations of the silanol groups, supports our earlier assumption that an increase in the passivation efficiency upon incorporation of VS into the mixture is due to the ability of such a network to prevent the desorption of the main CI.
\end{abstract}

Keywords: magnesium, mixed corrosion inhibitors, sodium oleate, vinyltrimethoxysilane, electrochemical impedance spectroscopy, FTIR spectroscopy. 


\section{Introduction}

Magnesium alloys are promising structural materials that remain the main competitors of aluminum alloys in areas where weight characteristics are important. Due to the high reactivity of $\mathrm{Mg}$, it instantly reacts with atmospheric oxygen in the absence of water to form an oxide [1,2]. However, as a rule, after interaction with water vapor from the air or with water in a solution, there is a film on the $\mathrm{Mg}$ surface, which consists of a $\mathrm{MgO}$ inner layer and an outer porous layer of $\mathrm{Mg}(\mathrm{OH})_{2}$ [3-5]. Due to the solubility of magnesium oxide and hydroxide, such films is not stable toward neutral and acidic aqueous solutions. As a result, they have insufficient protective properties; therefore, magnesium alloys cannot be used without additional protection.

The effect of $\mathrm{pH}$ on the corrosion behavior of $\mathrm{Mg}$ and its alloys is the subject of many studies. Regardless of the composition of the studied medium, a general trend is observed: the anodic dissolution of $\mathrm{Mg}$ slows down with an increase in the electrolyte $\mathrm{pH}$ [6-10]. However, it is reported [5] that even high purity $\mathrm{Mg}$ is not passive but is active under all experimental conditions, with the exception of a chromic acid solution. The rate of $\mathrm{Mg}$ dissolution increases continuously as the potential increases.

Improvement of the corrosion resistance can be achieved in different ways, for example, by reducing the concentration of impurities [11]. According to [5], a decrease in the content of impurities in $\mathrm{Mg}$ favorably affects its corrosion resistance and reaches a maximum at 99.85 wt.\% $\mathrm{Mg}$.

Alloying $\mathrm{Mg}$ with rare earth metals is another method of increasing its corrosion resistance [1,5]. The protection of $\mathrm{Mg}$ against corrosion is also achieved by applying conversion [12-17], anodic-oxide or sol-gel [18-20] and other coatings.

It was shown [21] that some pretreatments used in industry, including heat treatment, surface grinding and polishing, etching and sandblasting, also affect the corrosion characteristics of AZ31 magnesium alloy sheet. For example, surface grinding and acid etching enhance the corrosion resistance of $\mathrm{Mg}$, whereas sandblasting degrades it. The authors attribute this to the removal of Fe impurities during the first two types of treatment and incorporation of new contaminants and formation of microstresses in the sandblasting process.

The usage of corrosion inhibitors (CI) is one of the ways to increase the corrosion resistance of $\mathrm{Mg}$ and its alloys. CI can improve the protective effectiveness of the above mentioned coatings [22-25] or may be used by themselves $[25,26]$ for the protection during storage between operations. It has been shown earlier [27, 28] that sodium oleate (SOl) and some formulations based on it increase the corrosion resistance of commercially pure $\mathrm{Mg}$ with an oxide film formed in air. In this regard, it was of interest to study the effect of the thickness of the oxide layer on commercial $\mathrm{Mg}$ surface on the effectiveness of its protection against corrosion by formulations based on $\mathrm{SOl}$. 


\section{Experimental}

An alloy of commercially pure $\mathrm{Mg}(\mathrm{Mg} 90)$ with the following composition: $\mathrm{Mg}-99.9 \%$, $\mathrm{Fe}-$ up to $0.04 \%, \mathrm{Mn}-$ up to $0.03 \%, \mathrm{Al}-$ up to $0.02 \%, \mathrm{Ni}-$ up to $0.001 \%, \mathrm{Cu}-$ up to $0.004 \%, \mathrm{Si}$ - up to $0.009 \%, \mathrm{Cl}-$ up to $0.005 \%$ was chosen as the main object of research. The samples were preliminarily ground on emery papers from P240 to 1000 grit and degreased with acetone. Then a system of coatings consisting of an oxide-hydroxide sublayer and an CI film was formed.

The hydroxide layer was formed in two ways:

1. Magnesium samples were degreased for $10 \mathrm{~min}$ in an alkaline solution of $45 \mathrm{~g} / \mathrm{L}$ $\mathrm{NaOH}$ and $10 \mathrm{~g} / \mathrm{L} \mathrm{Na} \mathrm{PO}_{4} \cdot 12 \mathrm{H}_{2} \mathrm{O}$ [29] at $60^{\circ} \mathrm{C}$, then washed with water and dried in air for $60 \mathrm{~min}(\mathrm{Ox} / \mathrm{Phos})$.

2. Magnesium samples were chemically oxidized in $5 \mathrm{M} \mathrm{NaOH}$ for $90 \mathrm{~min}$, then washed with distilled water and dried in air for $60 \mathrm{~min}(\mathrm{Ox})$.

Two- and three-component mixtures of SOl with sodium flufenaminate (SFF), sodium salts of alkenylsuccinic acids (SAS), and vinyltrimethoxysilane (VS), $\mathrm{H}_{2} \mathrm{C}=\mathrm{CHSi}\left(-\mathrm{OCH}_{3}\right)_{3}$ were used as potential CIs. SFF and SAS solutions were prepared by neutralizing the corresponding acids with $\mathrm{NaOH}$. Since VS is unstable in water, its concentrate was prepared as a $100 \mathrm{mM}$ solution in isopropyl alcohol.

Samples of $\mathrm{Mg} 90$ with an oxide film were kept in solutions with the compositions shown in Table 1 and then dried in air.

Table 1. Compositions of passivating solutions and treatment modes.

\begin{tabular}{|c|c|c|c|c|}
\hline \multirow{2}{*}{ No. } & \multirow{2}{*}{ Solution composition, $\mathrm{mM}$} & \multirow{2}{*}{$\mathbf{p H}$} & \multicolumn{2}{|c|}{ Exposure time in solution $(t)$, min } \\
\hline & & & 10 & 60 \\
\hline 1 & $16 \mathrm{mM} \mathrm{SOl}$ & 8 & + & + \\
\hline 2 & $12 \mathrm{mM} \mathrm{SOl}+4 \mathrm{mM} \mathrm{VS}$ & 8.2 & + & + \\
\hline 3 & $\begin{array}{c}8 \mathrm{mM} \mathrm{SOl}+8 \mathrm{mM} \mathrm{SFF} \\
(16 \mathrm{mM} \text { IFKhAN 25F })\end{array}$ & 7.5 & + & + \\
\hline 4 & $\begin{array}{c}6 \mathrm{mM} \mathrm{SOl}+6 \mathrm{mM} \text { SFF } \\
(12 \mathrm{mM} \text { IFKhAN 25F) + } 4 \text { mM VS }\end{array}$ & 7.7 & + & + \\
\hline 5 & $12 \mathrm{mM} \mathrm{SOl}+4 \mathrm{mM}$ SAS & 7.8 & + & + \\
\hline 6 & $9 \mathrm{mM} \mathrm{SOl}+3 \mathrm{mM} \mathrm{SAS}+4 \mathrm{mM} \mathrm{VS}$ & 7.76 & + & + \\
\hline
\end{tabular}

The protective aftereffect of the resulting films was evaluated by recording anodic polarization curves and electrochemical impedance spectra (EIS) and by direct corrosion tests with periodic moisture condensation. 
Anodic polarization curves were recorded in a three-electrode glass cell with divided spaces using an IPC-Pro MF potentiostat $(\mathrm{RF})$. The potentials $(E)$ of $\mathrm{Mg} 90$ were measured relative to a silver chloride reference electrode and recalculated to the standard hydrogen scale. A platinum auxiliary electrode was used. Polarization curves were recorded on an electrode without and with a CI adsorption film already formed in solutions (Table 1). After drying for 1 hour at room temperature, samples treated for $t$ minutes were lowered into the cell and anodic polarization was started immediately, i.e., from the initial potential $\left(E_{\text {in }}\right)$.

EIS studies were carried out in a three-electrode glass cell with divided spaces using a "Solartron Schlumberger" computerized electrochemical set (United Kingdom) comprising a 1286 potentiostat and a 1250 frequency response analyzer (FRA). Samples were prepared in the same way as for electrochemical studies. EI spectra were obtained in the frequency range $\omega$ from $60 \mathrm{kHz}$ to $0.1 \mathrm{~Hz}$ with an alternating voltage amplitude of $10 \mathrm{mV}$. The working $\left(S_{\mathrm{w}}=0.72 \mathrm{~cm}^{2}\right)$ and auxiliary electrodes (a platinum grid with an area of $S_{\mathrm{Pt}}=20 \mathrm{~cm}^{2}$ ) were placed coaxially in the electrochemical cell. The potentials of the $\mathrm{Mg}$ electrodes were measured relative to a silver/silver chloride electrode. The studies were carried out in borate buffer solution ( $\mathrm{pH} 9.2$ ) containing $1 \mathrm{mM} \mathrm{NaCl}$ with natural aeration.

The working electrode was kept for $15 \mathrm{~min}$ in the borate buffer at the free corrosion potential, then the resulting $E$ value was recorded, polarization was turned on, and the EIS measurement was started. The results were processed using the ZView program.

The hodograph of $\mathrm{Mg}$ in the working solution was described using the known equivalent electric circuit (EEC) of a coated electrode (Figure 1) [30-33]. It includes: resistance of the bulk electrolyte between the auxiliary and working electrodes $-R_{\mathrm{s}}$, resistance of surface layers - oxide-hydroxide and/or adsorption layer $-R_{\mathrm{f}}$, polarization resistance characterizing the electrochemical kinetics of the corrosion process $-R_{\mathrm{t}}$, constant phase element characterizing the capacitance of the surface layers and/or adsorption film $Q_{\mathrm{f}}$, and the capacitance of the electric double layer in the film defects expressed as a constant phase element $-Q_{\mathrm{dl}}$.

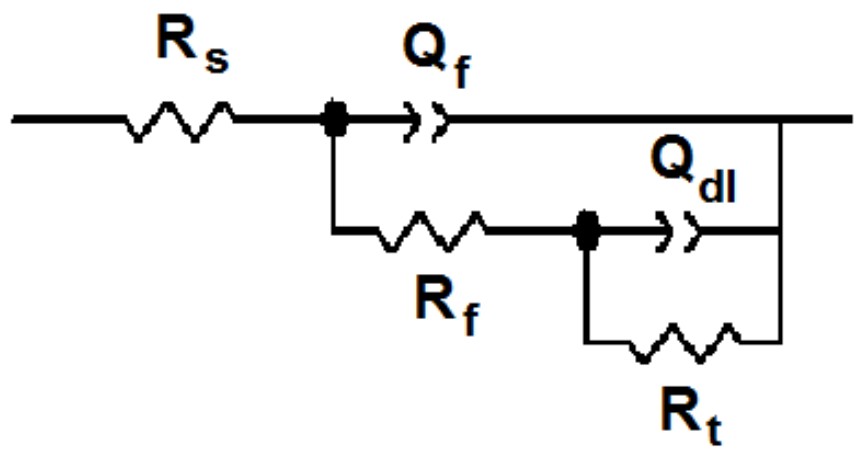

Figure 1. EEC of a coated electrode.

The degree of protection of a magnesium electrode was calculated by the following equation: 


$$
Z=\frac{R_{\mathrm{Ox}+\mathrm{CI}}-R_{\mathrm{Ox}}}{R} \cdot 100 \%
$$

where $R_{\mathrm{Ox}}$ and $R_{\mathrm{Ox}+\mathrm{CI}}$ are the total resistances of the metal-electrolyte interface interaction, including $R_{\mathrm{f}}$ and $R_{\mathrm{dl}}$, of an electrode with an oxide-hydroxide layer before and after treatment in CI solutions, respectively.

The results of calculating the EEC parameters, $R$ and $Z$ are presented in Tables 2 and 3.

Corrosion tests were carried out with periodic moisture condensation on rectangular specimens of $20 \times 30 \times 5 \mathrm{~mm}$ size prepared in the same manner as those used in the electrochemical studies. The prepared samples were suspended in glass cells above 40$50 \mathrm{ml}$ of distilled water at $t=40-50^{\circ} \mathrm{C}$. The cells with the samples were placed in a drying oven where $t=40 \pm 2^{\circ} \mathrm{C}$ was maintained for $8 \mathrm{~h}$, then heating was turned off, thus providing moisture condensation on the surface of the samples (GOST 9.308-85). The samples were examined every hour. The times when the first corrosion damage appeared $(\tau)$ were recorded.

The thicknesses of the hydroxide films were estimated using ex-situ ellipsometry. For this purpose, the ellipsometric angles $(\Delta$ and $\Psi)$ of the surface were measured before and after treatment. The calculation of the thicknesses of the passivating films was performed using the program available at http://www.ccn.yamanashi.ac.jp/ kondoh/ellips_e.html.

The chemical composition of both surface oxide layers and inhibitor films was studied by FTIR spectroscopy using a Nicolet 380 device (Thermo Electron Corp., USA) in diffuse reflection mode in the range of $400-4000 \mathrm{~cm}^{-1}$. The number of scans ranged from 64 to 364 . $\mathrm{Mg} 90$ plates with a size of $10 \times 10 \times 2 \mathrm{~mm}$ were used as the samples. Before measuring the spectra, the samples were grounded with sandpaper with grain size from 240 to 2000 grit and polished on felt with diamond paste. The diamond paste was removed and the samples were degreased for $5 \mathrm{~min}$ in an ultrasonic bath with acetone, then dried for $5 \mathrm{~min}$ in air. The prepared samples were further oxidized in different ways. Some of them were left in the air. Samples of the second group were kept for $10 \mathrm{~min}$ in a phosphate-alkaline solution [29] at $60^{\circ} \mathrm{C}$, washed with water, and dried in air. Samples of the third group were chemically oxidized for $90 \mathrm{~min}$ in a $5 \mathrm{M} \mathrm{NaOH}$ solution, washed with distilled water, and dried in air.

After drying, the plates were kept for $10 \mathrm{~min}$ in solutions of inhibitor formulations, then dried in air for $60 \mathrm{~min}$. Before FTIR measurements, the CI were adsorbed only on chemically oxidized Mg surfaces.

The FTIR spectra of the films were recorded in a similar mode, using a plate of oxidized Mg90 as the reference sample. The resulting spectra were transformed by the KubelkaMunk function using OMNIC 9 software.

\section{Results and Discussion}

Studies on the protective aftereffect of the films formed on $\mathrm{Mg} 90$ showed that the air-formed oxide-hydroxide film (Air/Ox) has weak protective properties. When the electrode is immersed in a solution and polarization is turned on, a rapid increase in the anodic current density is observed due to the active dissolution of $\operatorname{Mg}[27,28]$. 
According to ellipsometric measurements, after 10 minutes of degreasing in an alkaline phosphate solution, an oxide-hydroxide layer with a thickness of $\delta=13 \pm 1 \mathrm{~nm}$ is formed on $\mathrm{Mg}$ surface. The anodic curves obtained on such samples have a less negative initial potential, $E_{\text {in }}=-1.39 \mathrm{~V}$, than on samples with an oxide formed in air, $E_{\text {in }}=-1.57 \mathrm{~V}$, while the shape of the curves does not change. It is logical to associate the slight increase in $E_{\text {in }}$ with the inhibition of the anodic process.

Chemical oxidation of $\mathrm{Mg} 90$ in an alkali solution (Figures 2, 3) allows achieving stronger inhibition of the anodic dissolution of $\mathrm{Mg}$. In this case, the thickness of the oxide film was $80 \mathrm{~nm}$ [34]. Thus, with an increase in the thickness of the surface oxide-hydroxide layer, a slowdown of the anodic process is observed, and hence, an increase in the protection efficiency.

As shown earlier, treatment of Mg90 with an Air/Ox film in a $16 \mathrm{mM}$ solution of SOl for 10 min not only increases $E_{\text {in }}$ but also significantly reduces the anodic current density [34]. Exposure of $\mathrm{Mg}$ in a solution of this carboxylate insignificantly affects $E_{\text {in }}$ but slows down the anodic dissolution of $\mathrm{Mg}$. A sharp rise in the anodic polarization curve is observed only at $E \approx-0.69 \mathrm{~V}$, although in the absence of oxidation, SOl adsorption provided $E=$ $-0.85 \mathrm{~V}$ [34]. Earlier [28], the efficiency of protection of commercially pure $\mathrm{Mg}$ by films formed by mixtures of SOl with trialkoxysilanes in a neutral buffer solution and in a humid atmosphere was shown.

It was expected that the protective ability of CI adsorption films will gradually improve with an increase in the thickness of the oxide layer. According to electrochemical measurements, a 10-minute exposure of chemically degreased samples in solutions of $16 \mathrm{mM} \mathrm{SOl}$ and its mixture with silane ennobles $E_{\text {in }}$ (by 80 and $128 \mathrm{mV}$, respectively) relative to a similar background (Figure 2a). However, such preparation is not efficient enough in comparison with the adsorption of the aforementioned CIs even on a natural oxide, and even more so on an oxide formed upon 90-minute treatment of $\mathrm{Mg}$ in alkali. This is probably due to the fact that the phosphate anions contained in the degreasing solution are included in the composition of the oxide-hydroxide film and impede the subsequent adsorption of $\mathrm{CI}$ anions on the surface.

It was shown in [27] that addition of $8 \mathrm{mM}$ of an equimolar mixture of SOl with SFF to a borate solution with $\mathrm{pH} 9.2$ containing $1 \mathrm{mM} \mathrm{NaCl}$ provides the longest region with low current densities $(2.4 \mathrm{~V})$. In addition, the adsorption film of this CI favors a greater increase in $E_{\text {in }}$ than in the case of SOl itself. However, the region of potentials with low current densities was less extended in this case. Addition of SFF enhances the protection efficiency of $\mathrm{Mg} 90$ with an air-formed oxide film and under conditions of periodic moisture condensation [27]. In [28], we showed the possibility of enhancing the action of this mixture by adding trialkoxysilanes to it, while an increase in the treatment duration increases the efficiency of protection.

As one can see from Figure $2 \mathrm{~b}$ (curves 2 and 3), exposure of $\mathrm{Mg} 90$ with an oxide film with $\delta=13-14 \mathrm{~nm}$ in solutions of $8 \mathrm{mM} \mathrm{SOl}+8 \mathrm{mM} \mathrm{SFF}$ and $6 \mathrm{mM} \mathrm{SOl}+6 \mathrm{mM} \mathrm{SFF}+$ $4 \mathrm{mM}$ VS for $10 \mathrm{~min}$ ennobles $E_{\text {in }}$ by 80 and $70 \mathrm{mV}$, respectively (relative to the 
corresponding background). Thus, it can be seen that the protective effect of the oxidehydroxide $\mathrm{Mg}$ film is enhanced by the CI adsorption layers. Like in the case of SOl, this shift for its mixture with SFF is significantly smaller than for similar treatments of Mg90 with an air-formed oxide film, and the current densities suddenly increase in the region of potentials close to $E_{\text {in }}$ for chemically oxidized $\mathrm{Mg}$ without CI films.

The film formed in a solution of a $16 \mathrm{mM}$ equimolar mixture of SOl with SFF on a surface chemically pre-oxidized in $5 \mathrm{M} \mathrm{NaOH}$ favors the displacement of $E_{\text {in }}$ of the electrode in cathodic direction (Figure $2 b$ ) relative to a similar background. This is probably due to the partial dissolution of the hydroxide film upon exposure to the CI. Replacing a fraction $(4 \mathrm{mM})$ of the mixture with VS has practically no effect on the character of the anodic polarization curve of $\mathrm{Mg} 90$ in a weakly alkaline borate solution containing $1 \mathrm{mM} \mathrm{NaCl}$.

It was shown $[27,35]$ that a combination of $\mathrm{SO}$ and SAS in a ratio of $3: 1$ can provide effective protection of not only aluminum but also magnesium. An increase in the coating drying temperature from 20 to $65^{\circ} \mathrm{C}$ significantly enhanced the protective effect on $\mathrm{Mg} 90$.

Here, we investigated the properties of an adsorption film of SOl with SAS formed on oxide films with various thicknesses dried at $20^{\circ} \mathrm{C}$. Despite the fact that this composition is inferior to SOl in inhibition of the anodic dissolution of $\mathrm{Mg} 90$ with an air-formed oxide, incorporation of the silane into it significantly increases $E_{\text {in }}$ (by $0.63 \mathrm{~V}$ ), which indicates an increase in the protective effect (Figure 2c). Exposure for $10 \mathrm{~min}$ in solutions of $12 \mathrm{mM} \mathrm{SOl}$ $+4 \mathrm{mM} \mathrm{SAS}$ and $9 \mathrm{mM} \mathrm{SOl}+3 \mathrm{mM} \mathrm{SAS}+4 \mathrm{mM}$ VS favors a decrease in the $E_{\text {in }}$ of the electrode (by 0.12 and $0.16 \mathrm{~V}$, respectively). However, the anodic polarization curves demonstrate inhibition of anodic dissolution. A sharp increase in the anodic current densities on the curve obtained in a solution of $12 \mathrm{mM} \mathrm{SOl}+4 \mathrm{mM}$ SAS is observed at higher potentials than in the case of $\mathrm{SOl}(\mathrm{E} \sim-0.5 \mathrm{~V})$.

Increasing the time of electrode exposure in CI solutions from 10 to $60 \mathrm{~min}$ has a positive effect on the inhibition of the anodic dissolution of all the CIs studied (Figure 3a,b,c). This is manifested in a greater displacement of $E_{\text {in }}$ in anodic direction. However, on some anodic curves, there are regions with negative current density values (cathodic loops) due to the cathodic reaction of hydrogen evolution. The addition of silane enhances the inhibition of the anodic process by CI films in most cases. This is especially pronounced in the anodic curves of Mg90 with films obtained from solutions of $8 \mathrm{mM} \mathrm{SOl}+8 \mathrm{mM} \mathrm{SFF}$ and $6 \mathrm{mM}$ $\mathrm{SOl}+6 \mathrm{mM} \mathrm{SFF}+4 \mathrm{mM}$ VS. Replacement of $4 \mathrm{mM}$ mixed CI by VS favors the formation of films, which either significantly ennoble the $E_{\text {in }}$ of the electrode or inhibit the anodic dissolution to a greater extent.

Interestingly, the anodic curves of samples with films obtained from solutions of the $\mathrm{SOl}+$ SAS mixtures without and with addition of VS combined with 60 minutes of treatment (Figure 3c) demonstrated a correlation between the improvement of the protective properties and the increase in the thickness of the oxide-hydroxide layer. Among all treatment variants, the maximum protection of $\mathrm{Mg} 90$ was provided by the film of $9 \mathrm{mM} \mathrm{SOl}+3 \mathrm{mM} \mathrm{SAS}+$ $4 \mathrm{mM}$ VS formed in $60 \mathrm{~min}$ on a chemically pre-oxidized surface $(\delta=80 \mathrm{~nm})$. 

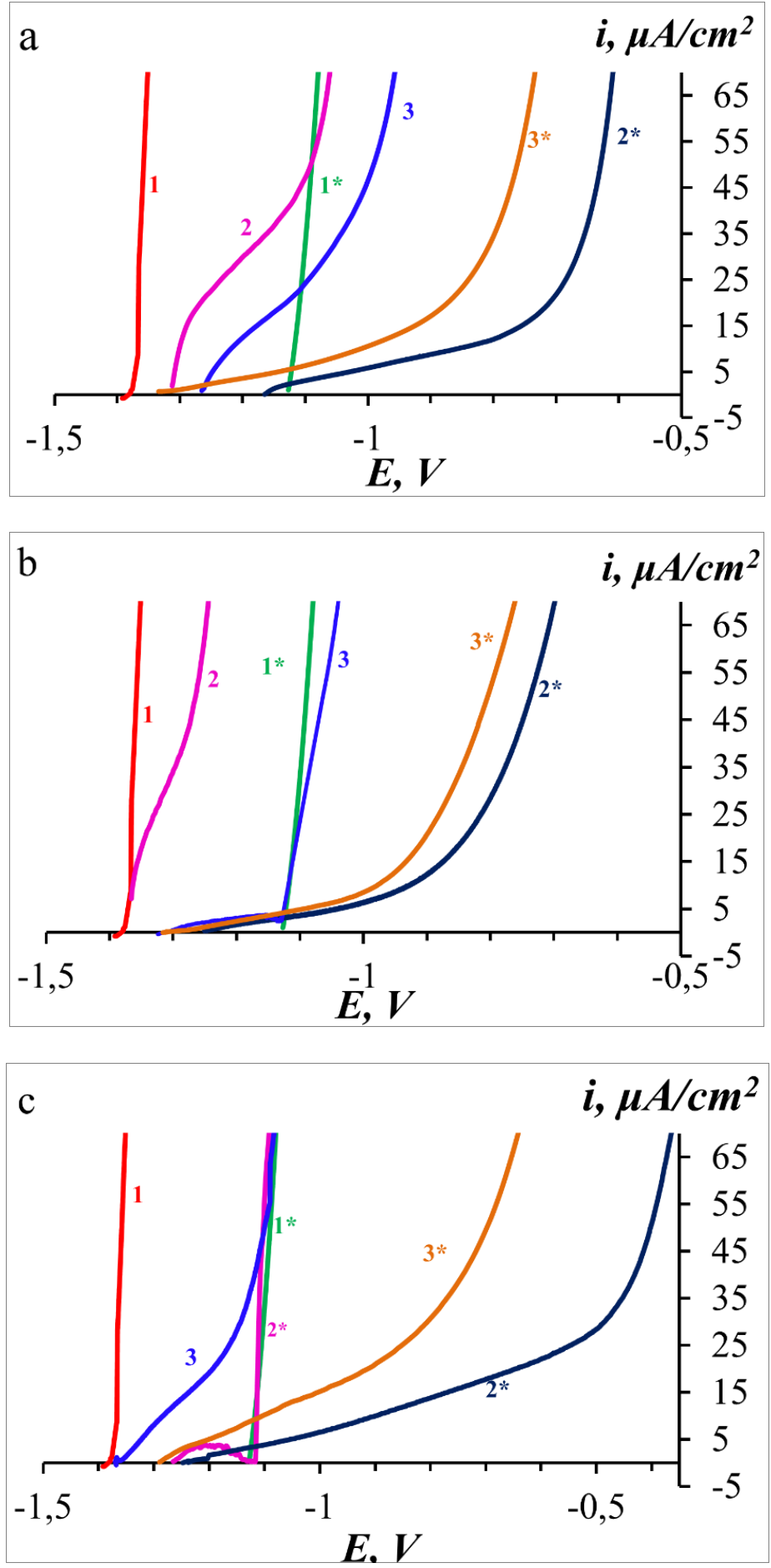

Figure 2. Anodic polarization curves of $\mathrm{Mg} 90$ in borate buffer $(\mathrm{pH} 9.2)+1 \mathrm{mM} \mathrm{NaCl}$ without -1 and after 10 min passivation in CI solutions: a: $2-16 \mathrm{mM} \mathrm{SOl} ; 3-12 \mathrm{mM} \mathrm{SOl}+4 \mathrm{mM}$ BC; b: 2 - 16 mM IFKhAN 25F; 3 - 12 mM IFKhAN 25F + 4 mM VS; c: $2-12 \mathrm{SOl}+4 \mathrm{mM}$ SAS; $3-12 \mathrm{mM}$ SAS $+3 \mathrm{mM}$ SAS $+4 \mathrm{mM}$ VS. Curves with numbers without an asterisk $\mathrm{Mg} 90$ after degreasing in the alkaline phosphate solution; * - after chemical oxidation in $5 \mathrm{M}$ $\mathrm{NaOH}$. 

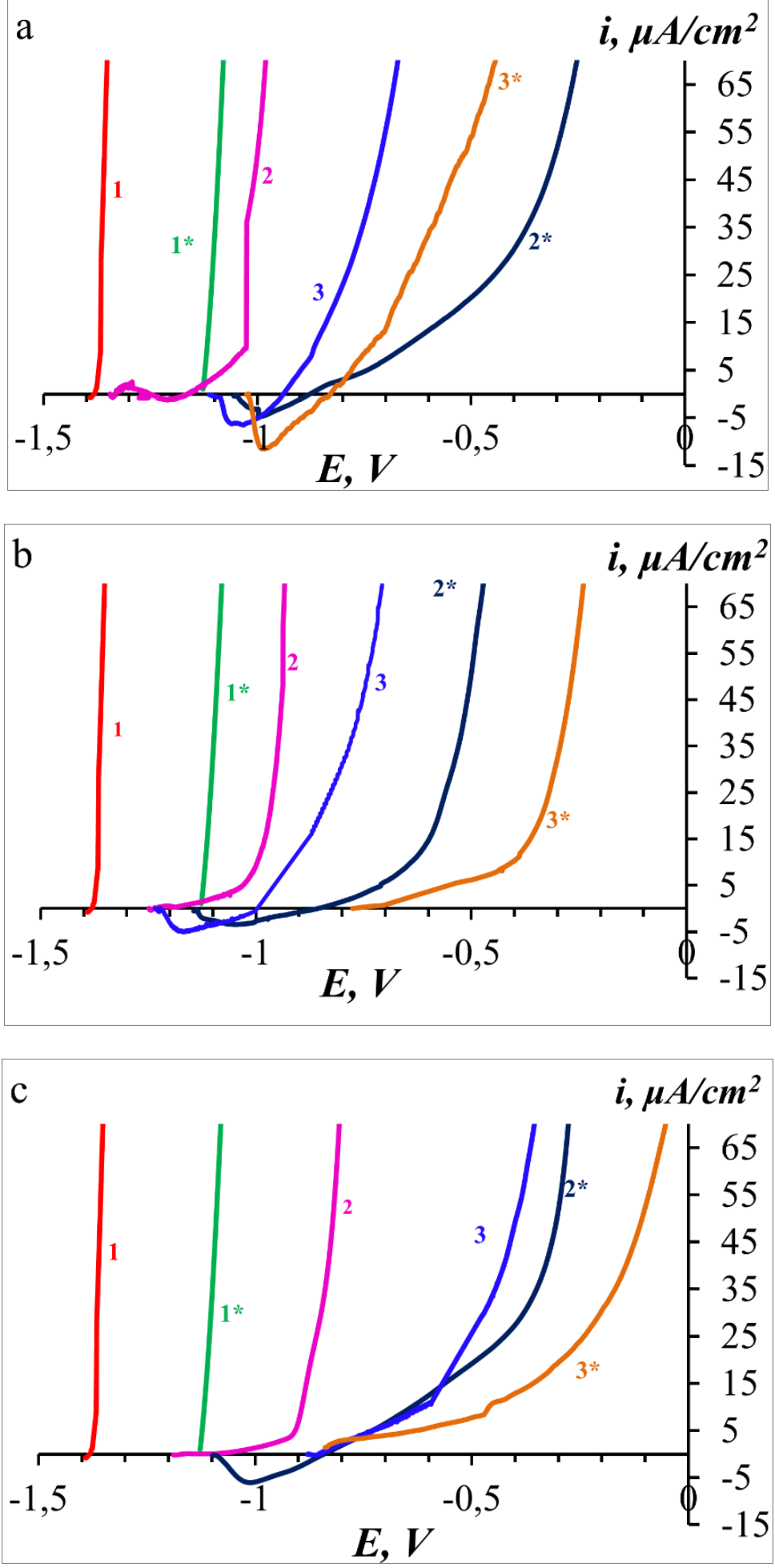

Figure 3. Anodic polarization curves of $\mathrm{Mg} 90$ in borate buffer $(\mathrm{pH} 9.2)+1 \mathrm{mM} \mathrm{NaCl}$ without -1 and after 60 min passivation in CI solutions: a: $2-16 \mathrm{mM} \mathrm{SOl} ; 3-12 \mathrm{mM} \mathrm{SOl}+4 \mathrm{mM}$ VS; b: 2 - 16 mM IFKhAN 25F; 3 - 12 mM IFKhAN 25F + 4 mM VS; c: $2-12 \mathrm{SOl}+4 \mathrm{mM}$ SAS; $3-12 \mathrm{mM} \mathrm{SOl} \mathrm{+} 3 \mathrm{mM}$ SAS $+4 \mathrm{mM}$ VS. Curves with numbers without an asterisk Mg90 after degreasing in an alkaline phosphate solution; * - after chemical oxidation in $5 \mathrm{M}$ $\mathrm{NaOH}$. 
EIS is another electrochemical method that makes it possible to assess the corrosion resistance of coatings. Figures 4 and 5 show the Nyquist plots of Mg90 samples in a borate solution containing $1 \mathrm{mM} \mathrm{NaCl}$ with various thicknesses of the oxide-hydroxide layer, without and with CI films.

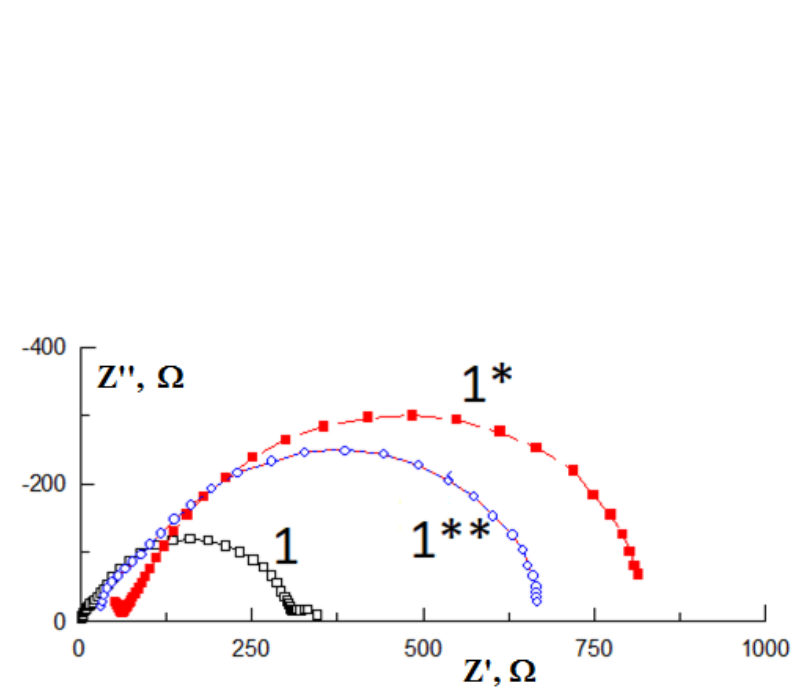

a

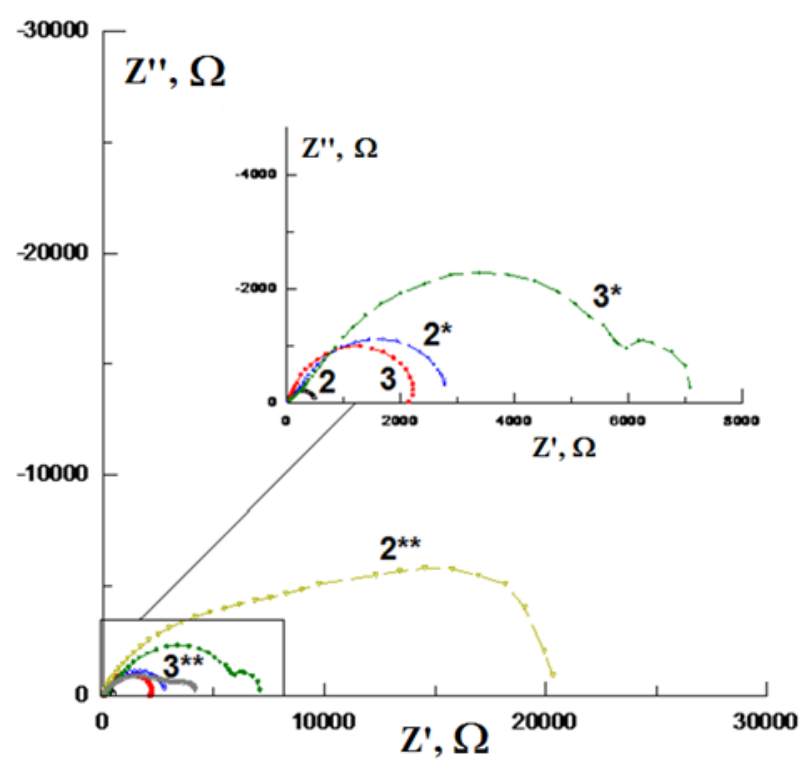

c

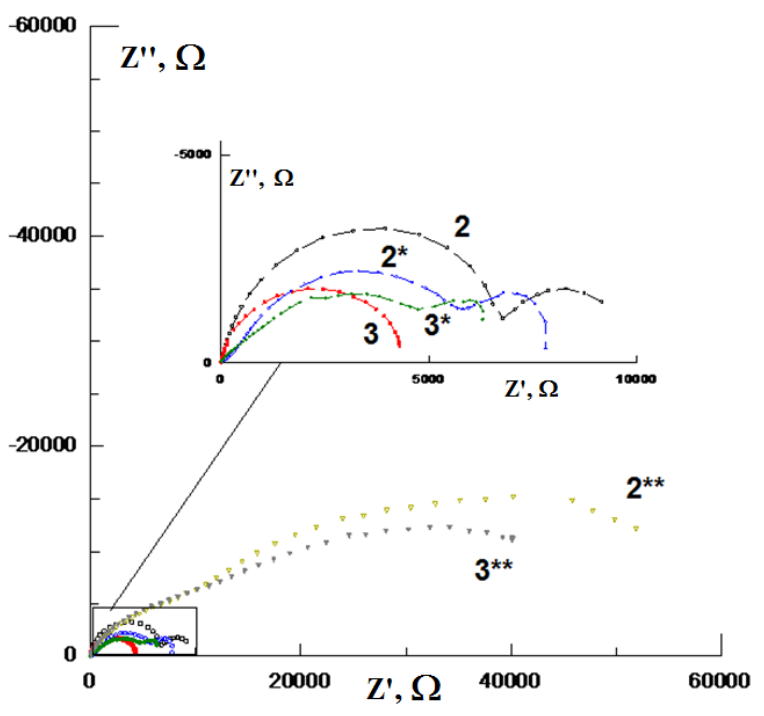

b

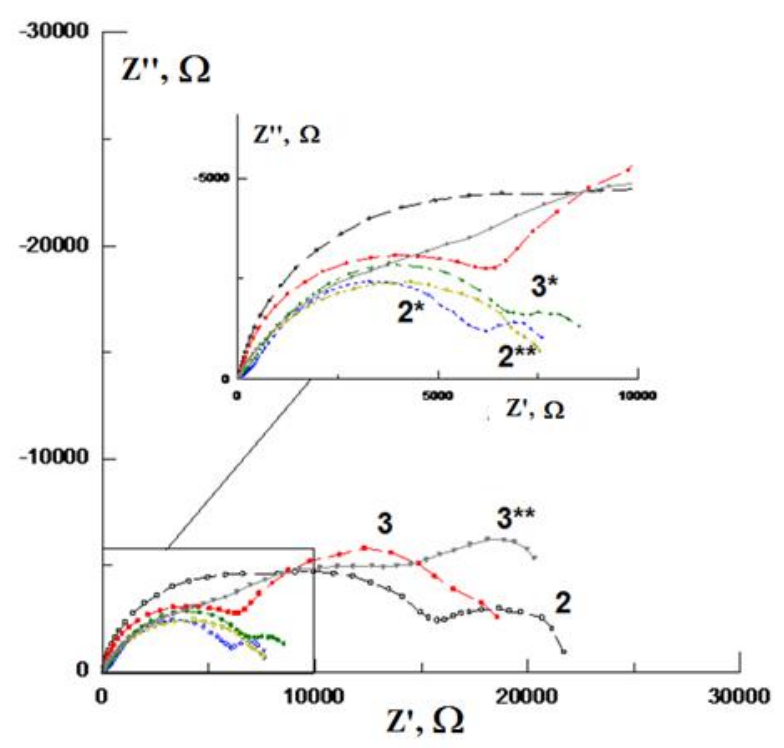

d

Figure 4. Nyquist plots obtained on $\mathrm{Mg} 90$ in borate buffer $(\mathrm{pH} 9.2)+1 \mathrm{mM} \mathrm{NaCl}$ without (a) and after 10 min passivation in CI solutions - (b, c, d): b: $2-16 \mathrm{mM} \mathrm{SOl} ; 3-12 \mathrm{mM} \mathrm{SOl}+$ 4 mM VS; c: 2 - 16 mM IFKhAN 25F; 3 - 12 mM IFKhAN 25F + 4 mM VS; d: 2-12 SOl + $4 \mathrm{mM}$ SAS; $3-12 \mathrm{mM} \mathrm{SOl}+3 \mathrm{mM}$ SAS + $4 \mathrm{mM}$ VS. Semicircles with numbers without an asterisk $-\mathrm{Mg} 90$ with an air-formed oxide film; ${ }^{*}-\mathrm{Mg} 90$ after degreasing in the alkaline phosphate solution; ** - after chemical oxidation in $5 \mathrm{M} \mathrm{NaOH}$. 


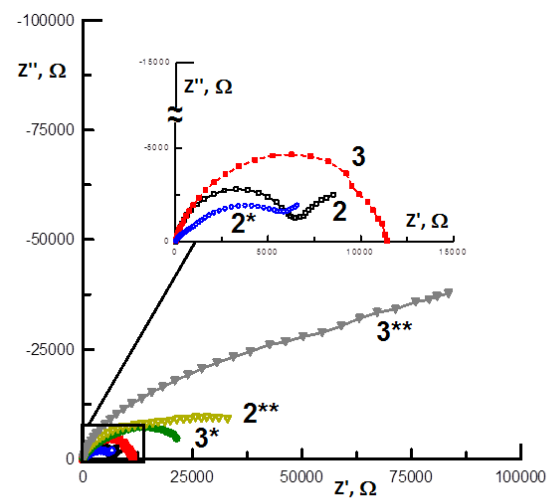

a

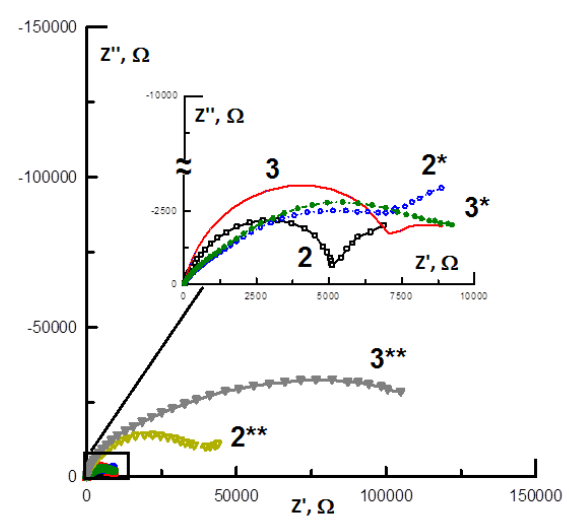

b

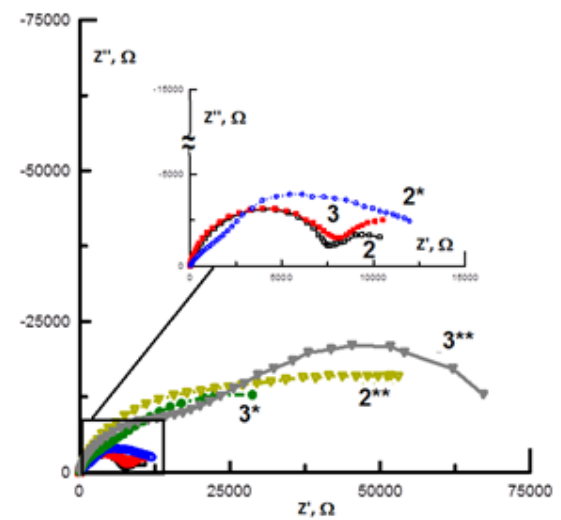

$\mathrm{c}$

Figure 5. Nyquist plots obtained on $\mathrm{Mg} 90$ in borate buffer $(\mathrm{pH} 9.2)+1 \mathrm{mM} \mathrm{NaCl}$ after 60 min passivation in CI solutions: a: $2-16 \mathrm{mM} \mathrm{SOl} ; 3-12 \mathrm{mM} \mathrm{SOl}+4 \mathrm{mM}$ VS; b: $2-$ 16 mM IFKhAN 25F; 3 - 12 mM IFKhAN 25F + 4 mM VS; c: 2 - 12 SOl + 4 mM SAS; 3 $12 \mathrm{mM} \mathrm{SOl}+3 \mathrm{mM}$ SAS $+4 \mathrm{mM}$ VS. Semicircles with numbers without an asterisk $-\mathrm{Mg} 90$ with an air-formed oxide film; * - Mg90 after degreasing in the alkaline phosphate solution; $* *$ - after chemical oxidation in $5 \mathrm{M} \mathrm{NaOH}$.

As seen from Figure 4a, a layer with a low total resistance $R=147 \Omega \cdot \mathrm{cm}^{2}$ is formed on the air-oxidized surface. The formation of an oxide-hydroxide layer from a phosphate or pure hydroxide solution increases the $R$ value by a factor of $2-3$, but it remains much lower than $1 \mathrm{k} \Omega \cdot \mathrm{cm}^{2}$ and the layer is not protective.

Let us consider how a 10-minute CI surface treatment affects the spectrum. It can be seen from Figure $4 \mathrm{~b}$ (curve 2) that its adsorption from a $16 \mathrm{mM}$ SOl solution on an airoxidized surface of sample significantly (36-fold) increases the resistance of the coating formed in this case. Pretreatment of the surface in a degreasing phosphate solution (semicircles $2^{*}$ ) results in a slightly smaller increase in $R$ after the adsorption of SOl, which is consistent with the measurements of $E$ under anodic polarization. The best results are obtained upon adsorption of the $\mathrm{CI}$ on a relatively thick oxide-hydroxide layer formed in $5 \mathrm{M} \mathrm{NaOH}$ in $90 \mathrm{~min}$ (semicircles $2 * *$ ). The addition of silane to the CI solution increases $R$ only for oxidized magnesium (semicircles $3 * *$ ), which can be associated with the greater thickness of the oxide-hydroxide layer formed in this case.

The use of a mixture of SOl with SFF (IFKhAN-25F) as the CI gave a greater scatter of results and lower absolute values than with $\mathrm{SOl}$ alone (Figure 4c). The $R$ value changes with an increase in the thickness of the oxide-hydroxide layer from $260 \Omega \cdot \mathrm{cm}^{2}$ for an airoxidized surface (semicircles 2) and $2.25 \mathrm{k} \Omega \cdot \mathrm{cm}^{2}$ for a phosphate-treated surface (semicircles $2^{*}$ ) to $10.2 \mathrm{k} \Omega \cdot \mathrm{cm}^{2}$ for an oxidized surface. (semicircles $2^{* *}$ ). The addition of VS to the CI formulation with the corresponding decrease in the concentrations of the other components gives a positive effect for the first two types of surface pretreatment, but decreases the $R$ value of the coating on the electrode oxidized in the alkaline solution (C $3 * *)$. 
The formulation of SOl with SAS (Figure 4d) shows good results on an air-oxidized surface (semicircles 2), but with other types of treatment, the resistance of the coating decreases relative to the above data. At the same time, significant progress is observed compared to surfaces not treated with a CI. The use of silane for this mixture shows a positive but not very significant effect.

One-hour treatment in a solution of $16 \mathrm{mM} \mathrm{SOl} \mathrm{(Figure} \mathrm{5a)} \mathrm{shows} \mathrm{itself} \mathrm{equally} \mathrm{well}$ on an air-oxidized surface (semicircles 2), after phosphate treatment (semicircles $2 *$ ), and especially on an oxidized electrode (semicircles $2^{* *}$ ). The effect of silane upon one-hour treatment is beneficial and quite significant in all cases (semicircles $3,3^{*}, 3^{* *}$ ). Apparently, in 1 hour, in contrast to the 10-minute treatment, the silane manages to polymerize in the pores of the oxide-hydroxide coating, thereby enhancing its protective properties. For the formulation of $12 \mathrm{mM} \mathrm{SOl}+4 \mathrm{mM} \mathrm{BC}$, a high level of protection is observed on the oxidized surface: $Z=99.89 \%, Z_{\mathrm{f}}=99.76 \%$.

One-hour treatment with a solution of $16 \mathrm{mM}$ IFKhAN-25F significantly increases the $R$ value in comparison with a 10-minute treatment by any of the methods (Figure 5b). The addition of VS to a CI solution gives a small effect for air-oxidized $\mathrm{Mg}$ surfaces degreased in the phosphate solution, but a more significant effect for oxidized magnesium: $Z=99.83 \%$, $Z_{\mathrm{f}}=99.63 \%$.

One-hour treatment of the $\mathrm{Mg}$ with the $\mathrm{SOl}+\mathrm{SAS}$ composition (Figure 5c), as in other cases, leads to an increase in $R$ as the thickness of the oxide-hydroxide layer increases. For an oxidized surface where CI shows the best protection $Z_{\mathrm{f}}=99.62 \%$. The introduction of silane into the composition of $\mathrm{CI}$ in all cases improves its protective properties, as evidenced by an increase in its resistance.

One-hour treatment of $\mathrm{Mg} 90$ by CI solutions gives a more stable coating, at least as shown by the EIS method, and the use of VS is more justified than in the case of a 10-minute treatment. The best results were shown by the following formulations: $12 \mathrm{mM} \mathrm{SOl}+4 \mathrm{mM}$ VS and $12 \mathrm{mM}$ IFKhAN 25F $+4 \mathrm{mM}$ VS if oxidized Mg was treated.

It may be noted that in the case of an air-oxidized $\mathrm{Mg}$ surface, in most cases, the powerlaw coefficient is $n_{\mathrm{dl}}>0.8$, and for an oxidized one, $n_{\mathrm{dl}}<0.5$. For a surface formed upon degreasing in the phosphate-alkaline solution, $n_{\mathrm{dl}}=0.5-0.7$. This suggests that an increase in the thickness of the oxide-hydroxide layer favors an increase in the heterogeneity of the coating, depending on the selected type of treatment.

Electrochemical methods are express methods for diagnosing the protective properties of coatings, but the results of accelerated corrosion tests can give a more accurate picture. In these tests, the accelerating factors include not only the constant high humidity of the atmosphere but also the regular condensation of moisture on the samples. The results of such tests under conditions of periodic moisture condensation of $\mathrm{Mg} 90$ with various types of oxide-hydroxide films without and after treatment in CI solutions are presented in Table 4. It follows from their analysis that the films formed on the air-formed oxide in solutions of the $8 \mathrm{mM} \mathrm{SOl}+8 \mathrm{mM} \mathrm{SFF}$ and $12 \mathrm{mM} \mathrm{SOl}+4 \mathrm{mM} \mathrm{SAS}$ formulations protect $\mathrm{Mg} 90$ from the first corrosion damage better than the film of SOl itself. However, the situation changes 
if the adsorption of CI was carried out on Mg90 previously oxidized in $5 \mathrm{M} \mathrm{NaOH}$. In this case, the inhibitors can arranged in following series: $\mathrm{SOl}<\mathrm{SOl}+\mathrm{SFF}<\mathrm{SOl}+\mathrm{SAS}$.

Table 2. Calculated parameters of $\mathrm{Mg} 90$ electrodes in borate buffer containing $1 \mathrm{mM} \mathrm{NaCl}$ with $\mathrm{pH} 9.2$, without and with CI films formed in $10 \mathrm{~min}$.

\begin{tabular}{|c|c|c|c|c|c|c|c|c|c|c|}
\hline CI & $\begin{array}{l}\text { Oxide } \\
\text { type }\end{array}$ & $\underset{\mu \mathrm{S} \cdot \mathrm{s}^{n} / \mathrm{cm}^{2}}{Q_{\mathrm{f}}}$ & $n_{\mathrm{f}}$ & $\begin{array}{c}R_{\mathrm{f}}, \\
\mathbf{\Omega} \cdot \mathrm{cm}^{2}\end{array}$ & $\begin{array}{c}Q_{\mathrm{dl}} \\
\mu \mathrm{S} \cdot \mathbf{s}^{n} / \mathbf{c m}^{2}\end{array}$ & $n_{\mathrm{dl}}$ & $\underset{\Omega \cdot \mathbf{c m}^{2}}{R}$ & $\begin{array}{c}R= \\
R_{\mathrm{f}}+R_{\mathrm{t}}, \\
\Omega \cdot \mathrm{cm}^{2}\end{array}$ & $Z, \%$ & $Z_{\mathrm{f}}, \%$ \\
\hline \multirow{3}{*}{$\begin{array}{l}\text { Without } \\
\text { CI }\end{array}$} & Air/Ox & 1.35 & 0.89 & 38.6 & 21.35 & 0.85 & 267 & 147 & - & - \\
\hline & Ox/Phos & 730 & 0.84 & 58.7 & 13.55 & 0.83 & 742 & 384 & 61.83 & - \\
\hline & Ox & 1.06 & 0.95 & 116.7 & 16.08 & 0.85 & 533 & 312 & 52.96 & - \\
\hline \multirow{3}{*}{ SOl } & Air/Ox & 0.92 & 0.91 & 7157 & 225 & 0.90 & 4070 & 5389 & 97.28 & 97.28 \\
\hline & Ox/Phos & 5.65 & 0.63 & 160.8 & 21.97 & 0.66 & 7315 & 5311 & 97.24 & 92.77 \\
\hline & Ox & 0.88 & 0.79 & 5558 & 15.56 & 0.46 & 75334 & 38828 & 99.62 & 99.20 \\
\hline \multirow{3}{*}{$\begin{array}{l}\mathrm{SOl}+ \\
\mathrm{VS}\end{array}$} & Air/Ox & 0.50 & 0.88 & 36.42 & 0.71 & 0.89 & 4338 & 2100 & 93.01 & 93.01 \\
\hline & Ox/Phos & 1.60 & 0.80 & 199.1 & 25.80 & 0.54 & 6620 & 4910 & 97.01 & 92.18 \\
\hline & Ox & 1.62 & 0.73 & 14306 & 13.51 & 0.38 & 79418 & 44988 & 99.67 & 99.31 \\
\hline \multirow{3}{*}{$\begin{array}{c}\text { IFKhAN } \\
25 \mathrm{~F}\end{array}$} & Air/Ox & 0.81 & 0.82 & 69.46 & 0.91 & 0.86 & 472 & 260 & 43.56 & 43.56 \\
\hline & Ox/Phos & 2.21 & 0.79 & 108 & 12.64 & 0.84 & 2653 & 2250 & 93.48 & 82.93 \\
\hline & Ox & 1.33 & 0.73 & 11418 & 6.14 & 0.89 & 9923 & 10244 & 98.57 & 96.95 \\
\hline \multirow{3}{*}{$\begin{array}{c}\text { IFKhAN } \\
25 \mathrm{~F}+ \\
\text { VS }\end{array}$} & Air/Ox & 1.35 & 0.73 & 86.52 & 0.30 & 0.98 & 2339 & 1746 & 91.60 & 91.60 \\
\hline & Ox/Phos & 9.93 & 0.67 & 474 & 7.89 & 0.78 & 6309 & 4884 & 97.00 & 92.14 \\
\hline & Ox & 2.55 & 0.69 & 0.1 & 16.77 & 0.30 & 3877 & 1861 & 92.12 & 83.23 \\
\hline \multirow{3}{*}{$\begin{array}{l}\mathrm{SOl}+ \\
\mathrm{SAS}\end{array}$} & Air/Ox & 1.80 & 0.86 & 11285 & 6.88 & 0.68 & 15856 & 19542 & 99.25 & 99.25 \\
\hline & Ox/Phos & 14.7 & 0.64 & 534 & 8.70 & 0.83 & 7070 & 5475 & 97.32 & 92.99 \\
\hline & Ox & 8.13 & 0.70 & 2161 & 1.91 & 0.71 & 7719 & 4742 & 96.91 & 93.42 \\
\hline \multirow{3}{*}{$\begin{array}{c}\mathrm{SOl}+ \\
\mathrm{SAS}+ \\
\text { VS }\end{array}$} & Air/Ox & 1.76 & 0.87 & 7700 & 22.68 & 0.84 & 14308 & 10564 & 98.61 & 98.61 \\
\hline & Ox/Phos & & & & 21.28 & 0.72 & 8580 & 4118 & 96.44 & 90.68 \\
\hline & Ox & 1.73 & 0.73 & 8114 & 31.44 & 0.41 & 118580 & 60813 & 99.76 & 99.49 \\
\hline
\end{tabular}

$Z$ - degree of protection against air-oxidized surface

$Z_{\mathrm{f}}-$ degree of protection in relation to the type of surface preparation; for air-oxidized surface, $Z_{\mathrm{f}}=Z$.

Replacement of $4 \mathrm{mM} \mathrm{SOl}$ and its compositions with VS increases the corrosion resistance of $\mathrm{Mg} 90$ (as compared to the initial solutions). The longest complete protection under conditions of periodic moisture condensation $(118-120 \mathrm{~h})$ is provided by a coating system consisting of a chemically formed oxide-hydroxide layer $(\delta=80 \mathrm{~nm})$ and an 
adsorption film formed in a solution of a three-component mixture of $6 \mathrm{mM} \mathrm{SOl}+6 \mathrm{mM}$ $\mathrm{SFF}+4 \mathrm{mM}$ VS. While in the case of EIS, increasing the time of exposure in CI solutions stabilized the coating, this parameter either did not have any effect or worsened the protective properties of the coatings in corrosion tests. The films of SOl + SAS and $\mathrm{SOl}+$ SAS + VS are the only exceptions.

Table 3. Calculated parameters of $\mathrm{Mg} 90$ electrodes in borate buffer containing $1 \mathrm{mM} \mathrm{NaCl}$ with $\mathrm{pH} 9.2$, without and with CI films formed in $60 \mathrm{~min}$.

\begin{tabular}{|c|c|c|c|c|c|c|c|c|c|c|}
\hline CI & $\begin{array}{c}\text { Oxide } \\
\text { type }\end{array}$ & $\underset{\mu \mathrm{S} \cdot \mathbf{s}^{n} / \mathbf{c m}^{2}}{Q_{\mathrm{f}}}$ & $n_{\mathrm{f}}$ & $\begin{array}{c}R_{\mathrm{f}}, \\
\Omega \cdot \mathrm{cm}^{2}\end{array}$ & $\underset{\mu \mathrm{S} \cdot \mathrm{s}^{n} / \mathbf{c m}^{2}}{Q_{\mathrm{dl}}}$ & $n_{\mathrm{dl}}$ & $\begin{array}{c}R \mathrm{t} \\
\Omega \cdot \mathrm{cm}^{2}\end{array}$ & $\begin{array}{c}R= \\
R_{\mathrm{f}}+R_{\mathrm{t}}, \\
\Omega \cdot \mathrm{cm}^{2}\end{array}$ & $Z, \%$ & $Z_{\mathrm{f}}, \%$ \\
\hline \multirow{3}{*}{$\mathrm{SOl}$} & Air/Ox & 0.042 & 0.98 & 46.6 & 2.17 & 0.88 & 7330 & 5311 & 97.24 & 97.24 \\
\hline & Ox/Phos & 0.60 & 0.84 & 15.0 & 31.84 & 0.52 & 8152 & 3920 & 96.26 & 90.20 \\
\hline & Ox & 0.91 & 0.86 & 0.1 & 13.35 & 0.32 & 55630 & 26702 & 99.45 & 98.83 \\
\hline \multirow{3}{*}{$\begin{array}{c}\mathrm{SOl}+ \\
\mathrm{VS}\end{array}$} & Air/Ox & & & & 1.59 & 0.84 & 11885 & 8557 & 98.29 & 98.29 \\
\hline & Ox/Phos & 2.1 & 0.80 & 7357 & 10.47 & 0.63 & 18900 & 18905 & 99.22 & 97.97 \\
\hline & Ox & 0.50 & 0.90 & 9486 & 8.58 & 0.43 & 170430 & 129540 & 99.89 & 99.76 \\
\hline \multirow{3}{*}{$\begin{array}{c}\text { IFKhAN } \\
25 \mathrm{~F}\end{array}$} & Air/Ox & 0.32 & 0.84 & 56.6 & 2.29 & 0.82 & 5507 & 4006 & 96.34 & 96.34 \\
\hline & Ox/Phos & 0.68 & 0.79 & 75.6 & 5.49 & 0.73 & 7724 & 5616 & 97.39 & 93.16 \\
\hline & Ox & 0.91 & 0.81 & 17400 & 1.16 & 0.79 & 39557 & 27339 & 99.46 & 98.86 \\
\hline \multirow{3}{*}{$\begin{array}{c}\text { IFKhAN } \\
25 \mathrm{~F}+ \\
\text { VS }\end{array}$} & Air/Ox & 0.21 & 0.88 & 56.7 & 0.85 & 0.90 & 7807 & 5662 & 97.41 & 97.41 \\
\hline & Ox/Phos & 0.46 & 0.81 & 25.35 & 15.12 & 0.61 & 9690 & 4663 & 96.85 & 91.77 \\
\hline & Ox & 0.99 & 0.88 & 15428 & 8.39 & 0.41 & 160000 & 84205 & 99.83 & 99.63 \\
\hline \multirow{3}{*}{$\begin{array}{c}\mathrm{SOl}+ \\
\text { SAS }\end{array}$} & Air/Ox & 1.00 & 0.75 & 80.22 & 0.50 & 0.90 & 7931 & 3845 & 96.19 & 96.19 \\
\hline & Ox/Phos & 4.35 & 0.73 & 2172 & 14.21 & 0.63 & 11420 & 6524 & 97.75 & 94.11 \\
\hline & Ox & 1.02 & 0.85 & 3015 & 6.00 & 0.34 & 111100 & 82163 & 99.82 & 99.62 \\
\hline \multirow{3}{*}{$\begin{array}{c}\mathrm{SOl}+ \\
\mathrm{SAS}+ \\
\text { VS }\end{array}$} & Air/Ox & 2.73 & 0.65 & 16.85 & 0.60 & 0.96 & 8607 & 4139 & 96.46 & 96.46 \\
\hline & Ox/Phos & 0.56 & 0.90 & 0.1 & 13.28 & 0.46 & 56331 & 40558 & 99.64 & 99.05 \\
\hline & Ox & 0.21 & 0.86 & 16054 & 19.23 & 0.58 & 74578 & 43503 & 99.66 & 99.28 \\
\hline
\end{tabular}

In most cases, the addition of the alkoxysilane increases the protective properties of the CI. This can be attributed to the ability of silanes to be hydrolyzed to silanols in water. The subsequent condensation of silanols gives a siloxane network on the metal surface, which probably prevents the desorption of a CI from it.

Some differences in the results of the two methods are due to different test conditions. In the case of electrochemical tests, the medium has a slightly alkaline $\mathrm{pH}$ and corrosive $\mathrm{NaCl}$ is present in it, whereas in direct corrosion tests there is a thin film of water containing 
a large amount of oxygen on Mg90 (conditions typical of atmospheric corrosion) but no corrosive ions.

Table 4. Results of corrosion tests of $\mathrm{Mg} 90$ with periodic moisture condensation.

\begin{tabular}{|c|c|c|c|c|}
\hline \multirow{5}{*}{ No. } & \multirow{2}{*}{\multicolumn{2}{|c|}{$\begin{array}{l}\text { The composition of the passivating solution and the } \\
\text { type of oxide-hydroxide sublayer }\end{array}$}} & \multicolumn{2}{|c|}{$\tau, \mathbf{h}$} \\
\hline & & & $\begin{array}{l}\text { After } 10 \text { min of } \\
\text { treatment }\end{array}$ & $\begin{array}{l}\text { After } 60 \text { min of } \\
\text { treatment }\end{array}$ \\
\hline & \multirow{3}{*}{ Without CI } & Air/Ox & $0.5-1$ & - \\
\hline & & $\mathrm{Ox} / \mathrm{Phos}$ & 23 & - \\
\hline & & Ox & $17-20$ & - \\
\hline \multirow{3}{*}{1} & \multirow{3}{*}{$16 \mathrm{mM} \mathrm{SOl}$} & Air/Ox & $18-20$ & $17-18$ \\
\hline & & Ox/Phos & 25.5 & 18 \\
\hline & & Ox & $92-96$ & 69 \\
\hline \multirow{3}{*}{2} & \multirow{3}{*}{$12 \mathrm{mM} \mathrm{SOl}+4 \mathrm{mM} \mathrm{VS}$} & Air/Ox & 26 & 19 \\
\hline & & Ox/Phos & 48.5 & 41 \\
\hline & & Ox & 103 & 65 \\
\hline \multirow{3}{*}{3} & \multirow{3}{*}{16 mM IFKhAN 25F } & Air/Ox & 23 & 25.5 \\
\hline & & Ox/Phos & 27.5 & 45 \\
\hline & & Ox & 58 & 66 \\
\hline \multirow{3}{*}{4} & \multirow{3}{*}{$12 \mathrm{mM}$ IFKhAN + $4 \mathrm{mM} \mathrm{VS}$} & Air/Ox & $23-24$ & $23-24$ \\
\hline & & Ox/Phos & $22-24$ & 41 \\
\hline & & Ox & $118-120$ & 117 \\
\hline \multirow{3}{*}{5} & \multirow{3}{*}{$12 \mathrm{mM} \mathrm{SOl}+4 \mathrm{mM} \mathrm{SAS}$} & Air/Ox & 21 & $20-22$ \\
\hline & & Ox/Phos & 26.5 & 46 \\
\hline & & Ox & 54.5 & 72 \\
\hline \multirow{3}{*}{6} & \multirow{3}{*}{$\begin{array}{c}9 \mathrm{mM} \mathrm{SOl}+3 \mathrm{mM} \mathrm{SAS}+ \\
4 \mathrm{mM} \mathrm{VS}\end{array}$} & Air/Ox & 33 & 30 \\
\hline & & Ox/Phos & 48 & 48 \\
\hline & & Ox & 63 & 73 \\
\hline
\end{tabular}

Fourier Transform Infrared (FTIR) spectroscopy was used to confirm the presence of components of inhibiting solutions on the Mg90 surface. For this purpose, FTIR spectra were obtained for oxide and inhibiting films. Figure 6a shows the spectrum of magnesium with a natural oxide-hydroxide layer. The wide intense band in the range from 3200 to $3900 \mathrm{~cm}^{-1}$ corresponds to the stretching vibrations of hydroxy groups in the surface layer. The spectrum of $\mathrm{Mg}$ subjected to chemical degreasing (Figure 6b) differs from the background one 
(Figure 6a). It can be seen in the figure that a band with a maximum at $1217 \mathrm{~cm}^{-1}$ appeared in the range of $\sim 1100-1500 \mathrm{~cm}^{-1}$. This is probably due to the incorporation of the phosphate anion into the oxide-hydroxide film during chemical degreasing.
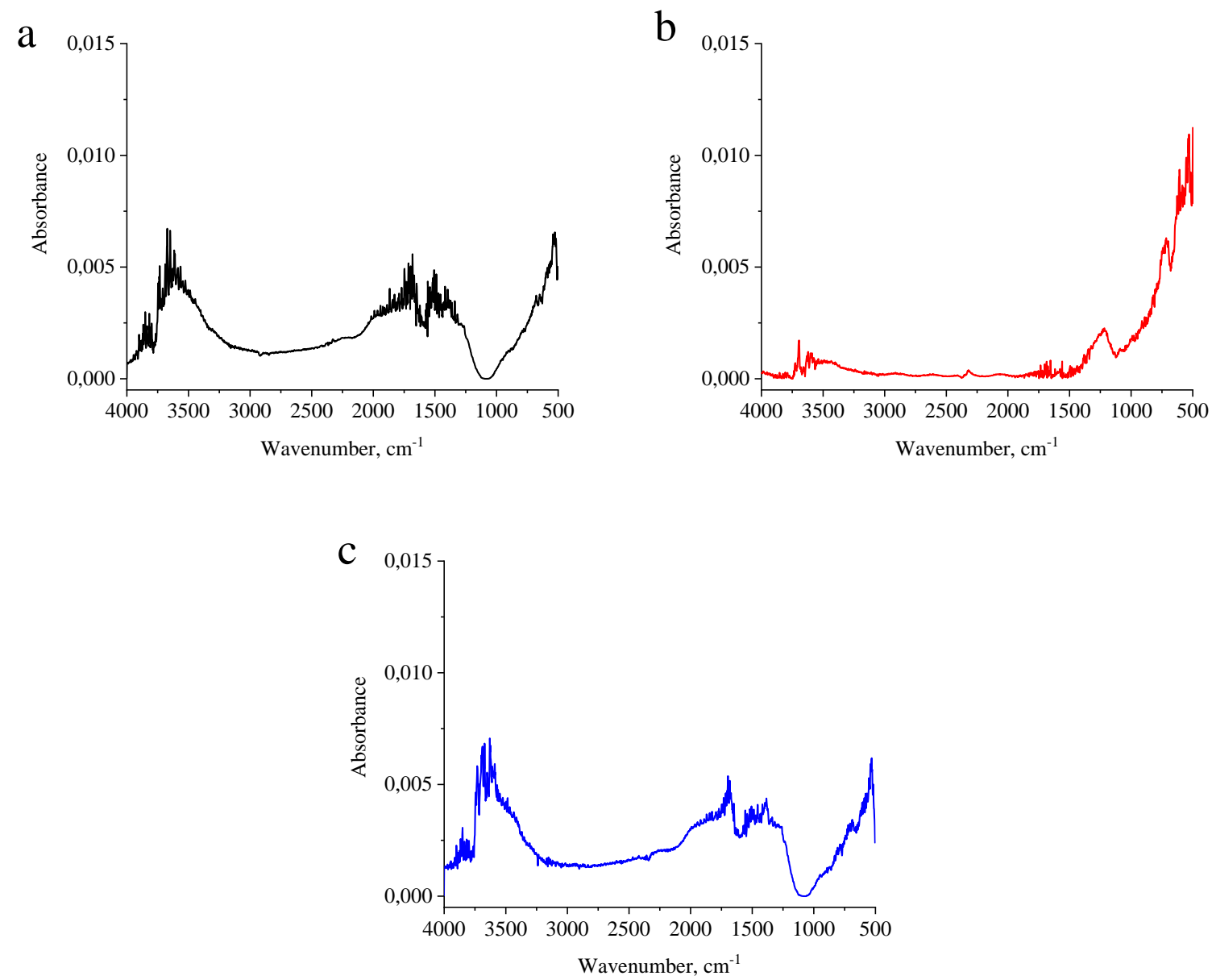

Figure 6. FTIR spectra of Mg90 samples with oxide films: a - Mg90 with an air-formed oxide-hydroxide film; $\mathrm{b}-\mathrm{Mg} 90$ after degreasing in the alkaline phosphate solution; $\mathrm{c}-\mathrm{Mg} 90$ after chemical oxidation in $5 \mathrm{M} \mathrm{NaOH}$.

The spectrum of $\mathrm{Mg} 90$ pre-oxidized in $5 \mathrm{M} \mathrm{NaOH}$ (Figure 6c) is identical to that recorded for samples without treatment. However, the intensity of the absorption bands in the spectrum of the oxidized sample is slightly higher. This indicates a greater layer thickness, while its composition is identical for both types of samples.

Figures 7 and 8 show the FTIR spectra of pre-oxidized Mg90 samples with adsorption layers of the studied CIs. Since all solutions contain SOl, all the spectra should contain the characteristic peaks of this compound. According to [36], a group of high-intensity bands in the region of $2850-2960 \mathrm{~cm}^{-1}$ corresponds to the stretching vibrations of the $\mathrm{C}-\mathrm{H}$ bond in the $-\mathrm{CH}_{3}$ and $=\mathrm{CH}_{2}$ groups of the hydrocarbon chain. They are present in all the spectra shown in Figures 7 and 8. In Figure 7a, the maxima of these peaks are observed at 2954, 2922 , and $2851 \mathrm{~cm}^{-1}$. In this case, the first band corresponds to the $\mathrm{CH}_{3}$-group, while the 
other two, to $\mathrm{CH}_{2}$. The broad bands observed in all the spectra in the region of 3010$3500 \mathrm{~cm}^{-1}$ characterize the stretching vibrations of the hydroxy groups. The bands belonging to the $\mathrm{R}-\mathrm{COO}^{-}$group are recorded in several wavenumber ranges. In particular, the carbonyl group of fatty monocarboxylic acids (including unsaturated ones in which the double bond is not in the $\alpha$ - or $\beta$-position) is characterized by an intense band in the region of 1705$1725 \mathrm{~cm}^{-1}[36,37]$. In the range of $1550-1650 \mathrm{~cm}^{-1}$, there is a band of asymmetric stretching vibrations in the $\mathrm{COO}^{-}$group [38]. Finally, the band in the range of $1440-1395 \mathrm{~cm}^{-1}$ refers to the stretching vibrations of the $\mathrm{C}-\mathrm{O}$ bonds and the in-plane bending vibrations of $\mathrm{O}-\mathrm{H}$, which are closely related to the former.

From the data shown in Figure 7a, it can be seen that in the case of SOl, the bands corresponding to the carboxy group have rather a low intensity. In our opinion, this is primarily due to the small thickness of the adsorption layer and, accordingly, the small number of such groups. In addition, impurities in the reagent and, as a consequence, in the composition of the adsorption layer can have a certain effect.

a

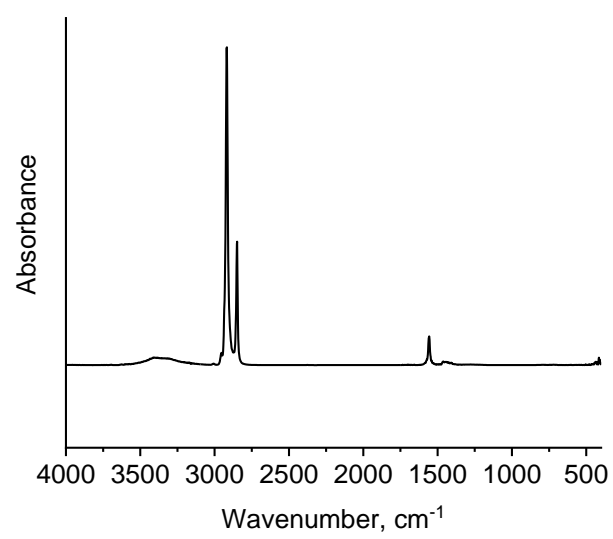

$\mathrm{b}$

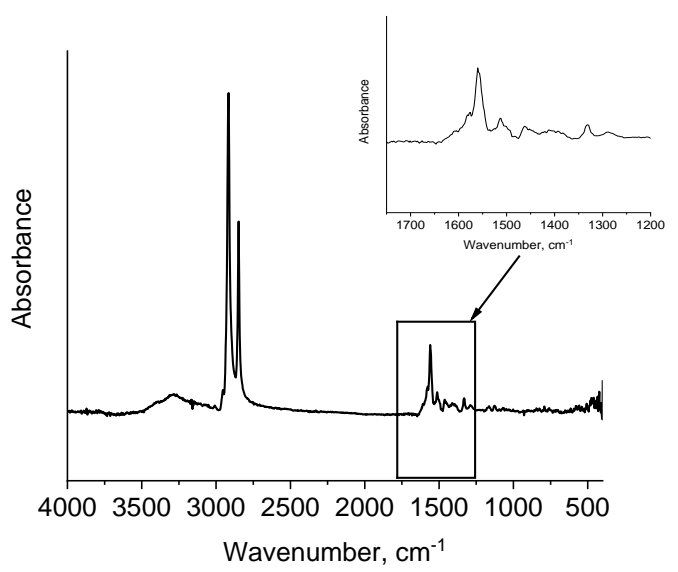

$\mathrm{c}$

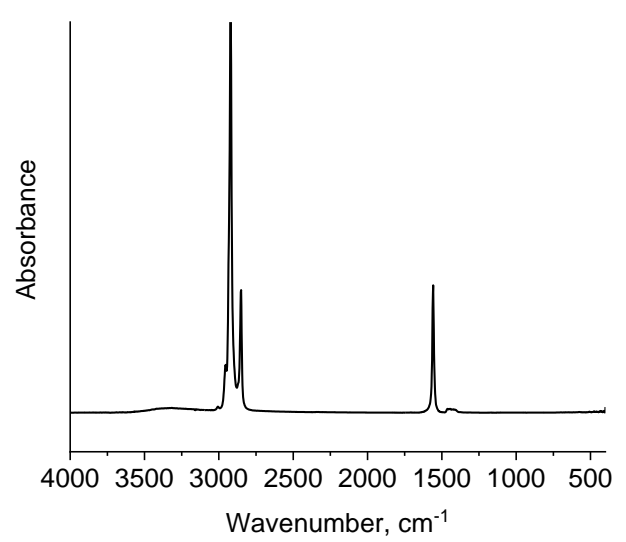

Figure 7. FTIR spectra of pre-oxidized $\mathrm{Mg} 90$ samples with adsorption layers of corrosion inhibitors: a $-16 \mathrm{mM} \mathrm{SOl}$; $\mathrm{b}-16 \mathrm{mM}$ IFKhAN 25F; c $-12 \mathrm{mM} \mathrm{SOl}+4 \mathrm{mM}$ SAS. The inset in Figure $b$ shows an enlarged section of the spectrum. 
While one symmetric band with a maximum at $1562 \mathrm{~cm}^{-1}$ is recorded in the spectrum of the SOl film in the range $1500-1640 \mathrm{~cm}^{-1}$, the shape of the band changes in the spectrum of the adsorption layer formed from a solution of its mixture with SFF (Figure 7b). Obviously, this is due to its partial overlap with the bands of the stretching vibrations of the $\mathrm{C}=\mathrm{C}$ group in the benzene ring and bending vibrations of the $\mathrm{N}-\mathrm{H}$ group in secondary amines. According to [39], both types of vibrations are observed in the range of 1550$1650 \mathrm{~cm}^{-1}$. An additional confirmation of the inclusion of SFF in the adsorption layer is the change in the band shape in the range of $3300-3500 \mathrm{~cm}^{-1}$, which is characteristic of the stretching vibrations of the $\mathrm{N}-\mathrm{H}$ group in secondary amines [38].

In turn, the inclusion of SAS into the adsorption layer is evidenced by a significant increase in the relative intensity of the absorption band in the range of $1504-1649 \mathrm{~cm}^{-1}$ that corresponds to the vibrations of carboxyl groups, which may be due to an increase in the number of these groups in the layer. Indeed, in contrast to SOl, SAS is a mixture of sodium salts of dicarboxylic acids.

a

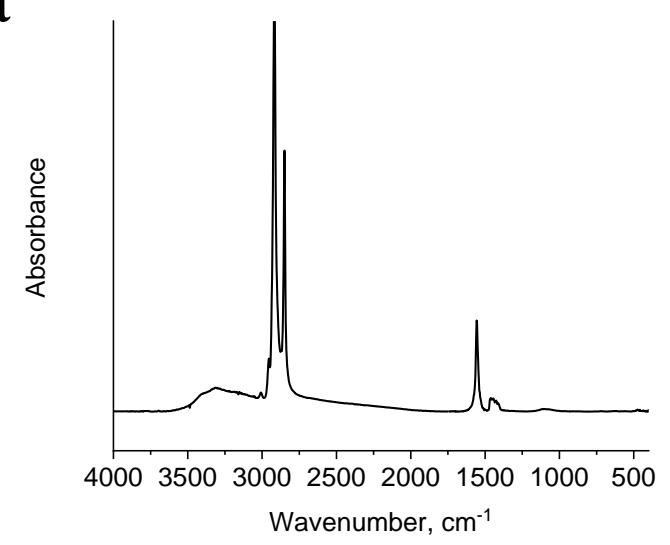

b

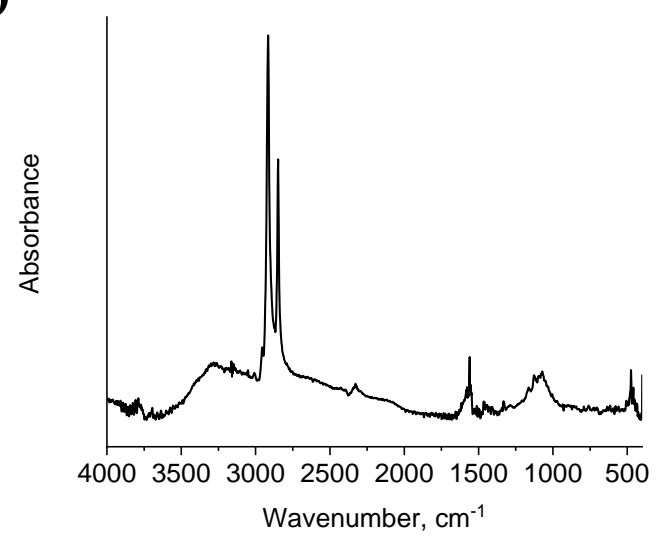

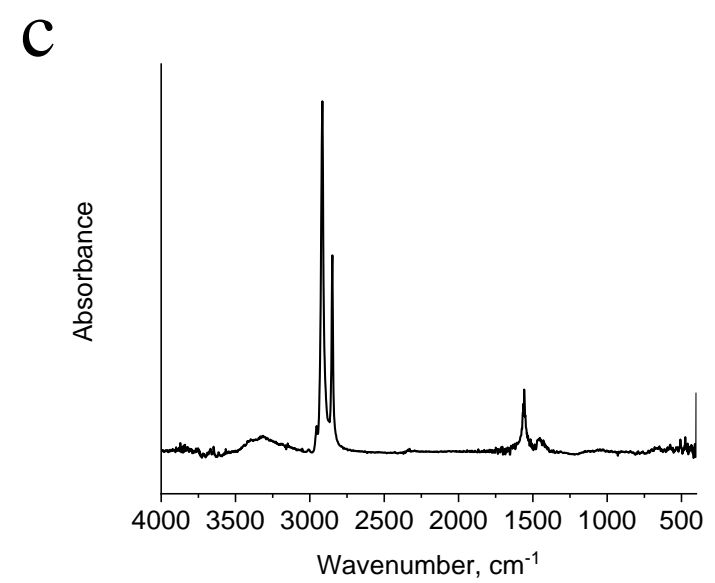

Figure 8. FTIR spectra of pre-oxidized Mg90 samples with films of corrosion inhibitors: a $12 \mathrm{mM} \mathrm{SOl}+4 \mathrm{mM} \mathrm{VS}$; $\mathrm{b}-12 \mathrm{mM}$ IFKhAN $25 \mathrm{~F}+4 \mathrm{mM} \mathrm{VS} ; \mathrm{c}-9 \mathrm{mM} \mathrm{SOl}+3 \mathrm{mM} \mathrm{SAS}+$ $4 \mathrm{mM}$ VS. 
Addition of VS to the system leads to additional changes in the FTIR spectra (Figure 8) of the samples obtained. It can be seen, in particular, that the spectra of all the three systems exhibit a broad band with a maximum near $3280 \mathrm{~cm}^{-1}$ caused by the stretching vibrations of silanol groups [40]. It is most intense in the spectrum of the sample with the composition $12 \mathrm{mM}$ IFKhAN 25F $+4 \mathrm{mM}$ VS (Figure 8b). The same sample is characterized by the presence of one more band in the range of $1000-1100 \mathrm{~cm}^{-1}$, which corresponds to the stretching vibrations of the $\mathrm{Si}-\mathrm{O}-\mathrm{Si}$ bonds. Obviously, in this case, hydrolysis and condensation of VS during the formation of the mixed adsorption layer take place, which leads to the formation of a network of siloxane bonds. The intensity of this band is very low, which can be due either to a small layer thickness or to a loose structure of the siloxane network. In our opinion, both of these processes occur in the remaining adsorption layers, but at a noticeably lower rate. Taking into account the close $\mathrm{pH}$ values for all the three systems, we assume that the main reason for the observed difference in rates lies in the composition of the reaction medium. Confirming this hypothesis will be one of our tasks at the next stage of our work.

\section{Conclusion}

1. An increase in the thickness of the oxide film favors an increase in the corrosion resistance of Mg90 without CI films. According to the corrosion tests and EIS data, the hydroxide layer obtained by degreasing in an alkaline phosphate solution has the best protective properties. This is due to the inclusion of phosphate, which itself is a $\mathrm{CI}$ of magnesium, into the composition of $\mathrm{Mg}(\mathrm{OH})_{2}$.

2. Polarization curves of $\mathrm{Mg} 90$ electrodes, previously kept for $10 \mathrm{~min}$ in solutions of $16 \mathrm{mM}$ $\mathrm{SOl}$ or a $\mathrm{CI}$ based on it, in a borate buffer containing $1.0 \mathrm{mM} \mathrm{NaCl}(\mathrm{pH} 9.2)$ indicate the greatest inhibition of the anodic dissolution of $\mathrm{Mg}$, particularly oxidized in $5.0 \mathrm{M} \mathrm{NaOH}$ and treated in a solution of $12 \mathrm{mM} \mathrm{SOl}+4 \mathrm{mM}$ SAS. Increasing the exposure time of the electrode in the CI solution from 10 to 60 min enhances the protective effect, but the best CIs are $12 \mathrm{mM}$ IFKhAN 25F $+4 \mathrm{mM}$ VS and $12 \mathrm{mM} \mathrm{SOl}+3 \mathrm{mM}$ SAS $+4 \mathrm{mM}$ VS.

3. EIS measurements carried out in a similar buffer solution but at the free corrosion potential confirm that treatment of $\mathrm{Mg} 90$ in a CI solution increases its protection with oxide films. An increase in the duration of such treatment in all cases increases the protective properties of the coatings. The formulation of $12 \mathrm{mM} \mathrm{SOl}+4 \mathrm{mM}$ VS was shown to be the best mixed $\mathrm{CI}$, in the solution of which a one-hour exposure of $\mathrm{Mg} 90$ samples chemically oxidized in $5 \mathrm{M} \mathrm{NaOH}$ provides a high degree of protection, i.e., $Z \sim 99.9 \%$. The slightly less efficient formulations include $12 \mathrm{mM}$ IFKhAN $25 \mathrm{~F}+4 \mathrm{mM}$ VS and $12 \mathrm{mM} \mathrm{SOl}+4 \mathrm{mM}$ SAS $(Z \sim 99.8)$.

4. According to the results of corrosion tests, an increase in the exposure time in a CI solution from 10 to 60 min either does not affect or worsens the protective properties of the coatings. The small discrepancies between electrochemical and corrosion data are due to differences in the experimental conditions. The longest protection under conditions of periodic moisture condensation is provided by films formed in $10 \mathrm{~min}$ on chemically 
oxidized Mg90 from solutions of $12 \mathrm{mM} \mathrm{SOl}+4 \mathrm{mM}$ VS and $12 \mathrm{mM}$ IFKhAN 25F + $4 \mathrm{mM}$ VS.

5. Information about the composition of the oxide-hydroxide layer and CI adsorption films on Mg90 surfaces was obtained using IR spectroscopy with Fourier transform (FTIR). The FTIR spectra confirmed the adsorption of SOl on the surfaces of Mg90 studied, while in the case of mixed CI, the adsorption of not only SOl but also SFF or SAS was shown. When VS is added to them, a band with a maximum at $3280 \mathrm{~cm}^{-1}$, which is due to the stretching vibrations of silanol groups in the case of adsorption layers formed by CI formulations of $12 \mathrm{mM}$ IFKhAN $25 \mathrm{~F}+4 \mathrm{mM}$ VS, becomes the most intense in the FTIR spectra. In this case, a band appeared in the range $1000-1100 \mathrm{~cm}^{-1}$ corresponding to the stretching vibrations of the $\mathrm{Si}-\mathrm{O}-\mathrm{Si}$ bonds, indicating the formation of a network of siloxane bonds. This is in favor of the previous assumption that such a network is capable of preventing the desorption of the main CI. The study of this phenomenon will be continued in our future works.

\section{References}

1. M. Esmaily, J.E. Svensson, S. Fajardo, N. Birbilis, G.S. Frankel, S. Virtanen, R. Arrabal, S. Thomas and L.G. Johansson, Fundamentals and Advances in Magnesium Alloy Corrosion, Prog. Mater. Sci., 2017, 89, 168. doi: 10.1016/j.pmatsci.2017.04.011

2. M. Liu, S. Zanna, H. Ardelean, I. Frateur, P. Schmutz, G. Song, A. Atrens and P. Marcus, A first quantitative XPS study of the surface films formed, by exposure to water, on $\mathrm{Mg}$ and on the $\mathrm{Mg}-\mathrm{Al}$ intermetallics: $\mathrm{Al}_{3} \mathrm{Mg}_{2}$ and $\mathrm{Mg}_{17} \mathrm{Al}_{12}$, Corros. Sci., 2009, 51, 1115-1127. doi: 10.1016/j.corsci.2009.02.017

3. M. Esmaily, D.B. Blücher, J.E. Svensson, M. Halvarsson and L.G. Johansson, New insights into the corrosion of magnesium alloys - the role of aluminum, Scr. Mater., 2016, 115, 91-95. doi: 10.1016/j.scriptamat.2016.01.008

4. H. Liu, F. Cao, G.-L. Song, D. Zheng, Z. Shi, M.S. Dargusch and A. Atrens, Review of the atmospheric corrosion of magnesium alloys, J. Mater. Sci. Technol., 2019, 35, 2003-2016. doi: 10.1016/j.jmst.2019.05.001

5. F. Cao, G.-L. Song and A. Atrens, Corrosion and Passivation of Magnesium Alloys, Corros. Sci., 2016, 111, 835-845. doi: 10.1016/j.corsci.2016.05.041

6. L. Rossrucker, A. Samaniego, J.-P. Grote, A.M. Mingers, C.A. Laska, N. Birbilis, G.S. Frankel and K.J.J. Mayrhofer, The $\mathrm{pH}$ Dependence of Magnesium Dissolution and Hydrogen Evolution during Anodic Polarization, J. Electrochem. Soc., 2015, 162, C333. doi: $10.1149 / 2.0621507$ jes

7. S. Alsagabi, J. Ninlachart, K.S. Raja and I. Charit, Passivity and Localized Corrosion of AZ31 Magnesium Alloy in High pH Electrolytes, J. Mater. Eng. Perform., 2016, 25, 2364-2374. doi: 10.1007/s11665-016-2101-9

8. S. Hiromoto, A. Yamamoto, N. Maruyama, H. Somekawa and T. Mukai, Influence of $\mathrm{pH}$ and flow on the polarisation behaviour of pure magnesium in borate buffer solutions, Corros. Sci., 2008, 50 3561-3568. doi: 10.1016/j.corsci.2008.09.026 
9. N. Dinodi and A.N. Shetty, Investigation of Influence of Medium $\mathrm{pH}$ and Sulfate Ion Concentrations on Corrosion Behavior of Magnesium Alloy ZE41, Surf. Eng. Appl. Electrochem., 2014, 50, no. 2, 149-156. doi: 10.3103/S1068375514020112

10. Z. Xu, U. Eduok, A.A. Tiamiyu and J. Szpunar, Anodic dissolution pattern of magnesium alloy in different media: Effects of solution treatment on microstructure and corrosion behaviour, Eng. Failure Anal., 2020, 107, 104234. doi: 10.1016/j.engfailanal.2019.104234

11. G. Song and A. Atrens, Understanding Magnesium Corrosion - A Framework for Improved Alloy Performance, Adv. Eng. Mater., 2003, 5, 837-858. doi: $\underline{10.1002 / \text { adem.200310405 }}$

12. M. Mosiałek, G. Mordarski, P. Nowak, W. Simka, G. Nawrat, M. Hanke, R.P. Socha and J. Michalska, Phosphate-permanganate conversion coatings on the AZ81 magnesium alloy: SEM, EIS and XPS studies, Surf. Coat. Technol., 2011, 206, no. 1, 51-62. doi: 10.1016/j.surfcoat.2011.06.035

13. J. Jayaraj, S.A. Raj, A. Srinivasan, S. Ananthakumar, U.T.S. Pillai, N.G.K. Dhaipule and U.K. Mudali, Composite magnesium phosphate coatings for improved corrosion resistance of magnesium AZ31 alloy, Corros. Sci., 2016, 113, 104-115. doi: 10.1016/j.corsci.2016.10.010

14. M.-Z. Bu, Z-X. Liu, T.-T. Wan and P.-C. Wang, A new phosphate pretreatment process for adhesive bonding of magnesium AZ31 sheets, J. Coat. Technol. Res., 2013, 10, no. 3, 347-359. doi: 10.1007/s11998-012-9451-5

15. K.H. Yang, M.D. Ger, W.H. Hwu, Y. Sung and Y.C. Liu, Study of vanadium-based chemical conversion coating on the corrosion resistance of magnesium alloy, Mater. Chem. Phys., 2007, 101, 480-485. doi: 10.1016/j.matchemphys.2006.08.007

16. L. Jianrui, G. Yina and H. Weidong, Study on the corrosion resistance of phytic acid conversion coating for magnesium alloys, Surf. Coat. Technol., 2006, 201, 1536-1541. doi: $10.1016 /$ j.surfcoat.2006.02.020

17. A.A. Abrashov, N.S. Grigoryan, M.A. Simonova and N.A. Asnis, Adgezionnye konversionnye pokrytiya pod LKP na magniyevykh splavakh (Adhesive conversion coatings for paintwork on magnesium alloys), Tsvetnye Metally, 2019, 10, 66-71 (in Russian). doi: $10.17580 /$ tsm.2019.10.11

18. S.A. Omar, J. Ballarre, Y. Castro, E. Martinez Campos, W. Schreiner, A. Duran and S.M. Cere, 58S and 68S sol-gel glass-like bioactive coatings for enhancing the implant performance of AZ91D magnesium alloy, Surf. Coat. Technol., 2020, 400, 126224. doi: 10.1016/j.surfcoat.2020.126224

19. H.R. Asemani, L. Luo and V. Mannari, Corrosion-resistant organic-inorganic hybrid pretreatments obtained by UV-initiated process suitable for primer-less coating systems, Prog. Org. Coat., 2020, 147, 105878. doi: 10.1016/j.porgcoat.2020.105878 
20. S.V. Oleynik, V.S. Rudnev, Yu.A. Kuzenkov， T.P. Jarovaja, L.F. Trubetskaja, N.N. Degtiarenko and P.M. Nedozorov, The protective properties of coatings on a magnesium alloy formed by plasma electrolytic oxidation in silicate electrolytes, Int. J. Corros. Scale Inhib., 2018, 7, no. 1, 78-86. doi: 10.17675/2305-6894-2018-7-1-7

21. G.-L. Songa and Z.Q. Xu, The surface, microstructure and corrosion of magnesium alloy AZ31 sheet, Electrochim. Acta, 2010, 55, 4148-4161. doi: 10.1016/j.electacta.2010.02.068

22. S.V. Oleinik, V.S. Rudnev, Yu.A. Kuzenkov, T.P. Yarovaya, L.F. Trubetskaya and P.M. Nedozorov, Ingibirovannye PEO-pokrytiya na magnievom splave Ma-8 (Inhibited PEO-coatings on magnesium alloy Ma-8), Korroz.: mater., zaschh. (Corrosion: materials, protection), 2015, 10,39-44 (in Russian).

23. J. Yanga, C. Blawert, S.V. Lamaka, D. Snihirova, X. Lu, S. Di and M.L. Zheludkevich, Corrosion protection properties of inhibitor containing hybrid PEO-epoxy coating on magnesium, Corros. Sci., 2018, 140, 99-110. doi: 10.1016/j.corsci.2018.06.014

24. A.A. Chirkunov, A.G. Rakoch, E.V. Monakhova, A.A. Gladkova, Z.V. Khabibullina, V.A. Ogorodnikova, M. Serdechnova, C. Blawert, Yu.I. Kuznetsov and M.L. Zheludkevich, Corrosion protection of magnesium alloy by PEO-coatings containing sodium oleate, Int. J. Corros. Scale Inhib., 2019, 8, no. 4, 1170-1188. doi: 10.17675/2305-6894-2019-8-4-22

25. Yu.I. Kuznetsov, Organic corrosion inhibitors: where are we now? A review. Part III. Passivation and the role of the chemical structure of organophosphates, Int. J. Corros. Scale Inhib., 2017, 6, no. 3, 209-239. doi: 10.17675/2305-6894-2017-6-3-1

26. A.A. Chirkunov and M.L. Zheludkevich, Corrosion inhibition of Elektron WE43 magnesium alloy in $\mathrm{NaCl}$ solution, Int. J. Corros. Scale Inhib., 2018, 7, no. 3, 376-389. doi: $10.17675 / 2305-6894-2018-7-3-8$

27. V.A. Ogorodnikova, Yu.I. Kuznetsov and A.A. Chirkunov, Ingibirovaniye korrozii splava Mg90 kompozitsiyami na osnove oleata natriya. Ch. I. Soli vysshikh alkenil- i arilkarboksilatov (Inhibition of corrosion of $\mathrm{Mg} 90$ alloy by compositions based on sodium oleate. Part I. Salts of higher alkenyl and aryl carboxylates), Korroz.: mater., zaschh. (Corrosion: materials, protection), 2020, 7, 25-32 (in Russian). doi: 10.31044/1813-7016-2020-0-7-25-32

28. V.A. Ogorodnikova, Yu.I. Kuznetsov and A.A. Chirkunov, Ingibirovaniye korrozii splava Mg90 kompozitsiyami na osnove oleata natriya. $\mathrm{CH}$. II. Khelatoreagenty i trialkoksisilany (Inhibition of corrosion of $\mathrm{Mg} 90$ alloy by compositions based on sodium oleate. Part II. Chelating agents and trialkoxysilanes), Korroz.: mater., zaschh. (Corrosion: materials, protection), 2020, 9, 18-24 (in Russian). doi: 10.31044/18137016-2020-0-9-18-24

29. Y. Liu, X. Yin, J. Zhang, S. Yu, Z. Han and L. Ren, A electro-deposition process for fabrication of biomimetic super-hydrophobic surface and its corrosion resistance on magnesium alloy, Electrochim. Acta, 2014, 125, 395-403. doi: 10.1016/j.electacta.2014.01.135 
30. X.-B. Chen, X. Zhou, T.B. Abbott, M.A. Easton and N. Birbilis, Double-layered manganese phosphate conversion coating on magnesium alloy AZ91D: Insights into coating formation, growth and corrosion resistance, Surf. Coat. Technol., 2013, 217, 147-155. doi: 10.1016/j.surfcoat.2012.12.005

31. J.R. Scully and S.T. Hensley, Lifetime Prediction for Organic Coatings on Steel and a Magnesium Alloy Using Electrochemical Impedance Methods, Corrosion, 1994, 50, no. 9, 705-716. doi: $10.5006 / 1.3293547$

32. L. Kouisni, M. Azzi, F. Dalard and S. Maximovitch, Phosphate coatings on magnesium alloy AM60. Part 2: Electrochemical behaviour in borate buffer solution, Surf. Coat. Technol., 2005, 192, 239-246. doi: 10.1016/j.surfcoat.2004.05.028

33. A.Yu. Luchkin, O.A. Goncharova, N.N. Andreev, I.A. Arkhipushkin, L.P. Kazansky and Yu.I. Kuznetsov, 5-Khlor-1,2,3-benzotriazol kak kamernyi ingibitor korrozii magnievogo splava MA8 (5-Chloro-1,2,3-benzotriazole as a chamber corrosion inhibitor for magnesium alloy MA8), Korroz.: mater., zaschh. (Corrosion: materials, protection), 2020, 4, 27-35 (in Russian). doi: 10.31044/1813-7016-2020-0-4-27-35

34. V.A. Ogorodnikova, Yu.I. Kuznetsov, N.P. Andreeva, A.Yu. Luchkin and A.A. Chirkunov, Adsorption of anions of higher carboxylic acids on magnesium from weakly alkaline aqueous solutions, Russ. J. Phys. Chem. A, 2020, 94, no. 4, 1104-1110 (in Russian). doi: 10.31857/S0044453720060187

35. A.M. Semiletov, Yu.I. Kuznetsov and A.A. Kolesnikova, O zashchite ot atmosfernoi korrozii alyuminievogo splava AD31 antikorrozionnoi prisadkoi KAP-25 (On protection against atmospheric corrosion of aluminum alloy AD31 by anti-corrosion additive KAP25), Korroz.: mater., zaschh. (Corrosion: materials, protection), 2019, 12, 17-22 (in Russian). doi: 10.31044/1813-7016-2019-0-12-17-22

36. E.I. Knerelman, R.S. Yarullin, G.I. Davydova, G.P. Startseva, V.Ya. Churkina, P.E. Matkovsky and S.M. Aldoshin, Sravnitel'nye osobennosti infrakrasnykh spektrov C18-karbonovykh kislot, ikh metilovykh efirov (biodizelya) i triglitseridov (rastitel'nykh masel) (Comparative features of infrared spectra of c18-carboxylic acids, their methyl esters (biodiesel) and triglycerides (vegetable oils)), Vestn. Kazan. Tekhnol. Univ., 2008, 6, 68-78 (in Russian).

37. B.N. Tarasevich, IR spectra of classes of organic compounds. Reference materials., Moscow State University named after M.V. Lomonosov, Department of Chemistry, Chair of Organic Chemistry, Moscow, 2012, 55 pp. (in Russian).

38. St. Thomas, Spectroscopic Tools. URL: http://www.science-and-fun.de/tools/

39. L.J. Bellamy, The Infra-red Spectra of Complex Molecules, Springer, 1963, 590. doi: 10.1007/978-94-011-6017-9

40. F. Yan, J. Jiang, X. Chen, S. Tian and K. Li, Synthesis and Characterization of Silica Nanoparticles Preparing by Low-Temperature Vapor-Phase Hydrolysis of $\mathrm{SiCl}_{4}$, Ind. Eng. Chem. Res., 2014, 53, 11884-11890. doi: 10.1021/ie501759w 